\title{
The Effect of Project-Based Learning (PjBL) Models on Improving Students' Understanding of Concepts, Retention, and Social Attitudes
}

\author{
Martha Berhitu \\ Sekolah Menengah Atas 1 Ambon \\ Johanis F. Rehena (*) \\ Universitas Pattimura \\ Hasan Tuaputty \\ Universitas Pattimura
}

$\begin{array}{ll}\text { Received: } & \text { February 29, } 2020 \\ \text { Revised: } & \text { June 22, } 2020 \\ \text { Accepted: } & \text { June 24, } 2020\end{array}$

\begin{abstract}
The Project-Based Learning (PjBL) model is oriented to problem identification, project implementation, and product presentation. This study aims to determine the effect of PjBL learning models and conventional learning on the understanding of student concepts, retention, and social attitudes of students of SMA 1 Ambon. The sample in this study were students of class XI IPA-1, totaling 39 students, and class XI IPA-3, totaling 39 students in the 2017/2018 Academic Year. The research design used was a nonequivalent pretest-posttest control group design. Data analysis uses inferential statistics, namely the One-Way ANOVA test. One-Way ANOVA test results showed that the significant value of understanding concepts, retention, and social attitudes was $0,000<0.05$. Based on the results of the study, it was concluded that there was an influence of the learning model on the understanding of concepts, retention, and social attitudes of Grade XI students of SMA 1 Ambon in studying the concept of the excretion system.
\end{abstract}

Keywords: project-based learning, understanding of concepts, retention, social attitudes

(*) Corresponding Author: rehena.jf@gmail.com, 085228854070

How to Cite: Berhitu, M., Rehena, J.F., \& Tuaputty, H. (2020). The effect of project-based learning (PjBL) models on improving students' understanding of concepts, retention, and social attitudes. Formatif: Jurnal Ilmiah Pendidikan MIPA, 10 (2): 143-152. http://dx.doi.org/10.30998/formatif.v10i2.5947

\section{INTRODUCTION}

Project-Based Learning is a learning model that uses problems as the first step in gathering and integrating new knowledge based on its experience in real-life activities. Project-Based Learning (PjBL) requires a comprehensive teaching approach in which the student learning environment is designed so that students can investigate authentic issues. In PjBL, students are given a complex, quite difficult, complete, but realistic project and then given enough help so that students can complete the task. The PjBL model is project-based learning to solve contextual problems in innovative and unique ways, and produce the output presented (Patton, 2012; Winarti \& Nurhayati, 2014, Trianto, 2014; Jagantara et al., 2014). Projects carried out by students can be done individually or in groups within a certain period with the final result in the form of products. The product is then presented with various creativity that students have. 
PjBL models have been used by researchers in improving concept understanding (Sastrika et al., 2013; Yance et al., 2013; Rumahlatu \& Sangur, 2017). Understanding concepts is one component in the cognitive domain. Pardo (2004) defines understanding concepts as a process of digging and defining meaning through communication. Students' understanding of concepts can be formed through interaction between teachers and students and peers. Through a good concept learning design, a person (directly or indirectly) will understand a previously unknown concept (Meyer \& Land, 2005).

Understanding concepts in biology learning can be developed through experimentation with an accurate observation so that situationally students engage actively and independently. Engaging directly is momentum so that students can remember and construct creative ideas towards the concepts studied so that they are stored longer in long time memory. According to Bhinnety (2008), that information stored in long-term memory is permanent, as it comes from firsthand experience. This does not mean that there is never any loss of information or forgetting the concepts studied, but the process of transforming the concept from short-time memory to long time memory (retention) may have led to the loss of the studied concepts.

An educational process is a form of social interaction so it is very natural if teachers or educators try to analyze the process in the form of sociology in the form of relationships between people and families, schools, and communities. Students' social attitudes can affect the completeness of learning in class, the higher the social attitude then the higher the learning completed as well as vice versa (Sufahmi \& Safitri, 2017). Social attitudes are not expressed by one but are noticed by people in his group. An example is a way students communicate and help each other.

Social attitudes are needed to establish relationships with others in daily life. Social attitudes are an act of a person to live in his community such as helping each other, mutual respect, interacting with each other, and so on. Gusti (2017) reports on aspects of social attitude scoring namely: Discipline, Honesty, Manners, Perseverance, Responsibility, Teamwork, Confidence, and Tolerance. Social attitudes are actions that can overcome various problems that exist in society by thinking together. By having a good social attitude in learning, the learning process will run well and students' learning outcomes will improve.

The biology learning process that occurs during this time in school has a tendency: repetition and memorization, students learn to fear wrongdoing, less encourage students to think creatively, and rarely practice problem solving (Yustyan et al., 2015). Teachers are also still implementing conventional learning systems (Latief et al., 2014), although the learning process has now been implemented from the 2013 curriculum. Whereas the 2013 Curriculum hints at every teacher implementing the learning process by applying a scientific approach by utilizing various learning resources (Susilo, 2016). Therefore in the learning process that implements curriculum 2013, every activity carried out in learning in school and outside in co-curricular and extracurricular activities occurs the learning process to develop morals and behaviors related to attitudes (Lestari \& Sukanti, 2016).

Based on the results of interviews and observations before data collection was conducted at SMA 1 Ambon, it was obtained information that teachers have used various cooperative learning models in biology learning, including student teams achievement division, numbered head together, and problem-based learning. However, the PjBL model has not been used to defend the concept of biology. Also, information obtained that students of grade XII IPA consisting of 4 classes identified that biology subject matter that has been studied in grade XI, obtained data $80 \%$ of students still consider the organ system, especially the excretion system is difficult material. The excretion system is difficult to study on the grounds of too much material and has new biological terms that sound foreign and many of the material are abstract. In developing the understanding of 
concepts and retention and social attitudes of students in biology learning, it can be facilitated by using varied and innovative models, strategies, and learning methods to find solutions to a problem, so that this research is important to know the influence of $\mathrm{PjBL}$ model on understanding the concept, retention and social attitude of grade XI students IPA SMA 1 Ambon.

\section{METODE}

This research is a quasi-experiment study to find out the influence of PjBL learning models and conventional learning on the understanding of student concepts, retention, and social attitudes of high school students 1 Ambon. The research design used is a nonequivalent pretest-posttest control group design involving retention (Table 1).

Table 1. Research Design

\begin{tabular}{cccccc}
\hline Group & Pretest & Treatment & Posttest & $\begin{array}{c}\text { Retention } \\
(1 \mathrm{Week})\end{array}$ & $\begin{array}{c}\text { Retention } \\
(2 \mathrm{Weeks})\end{array}$ \\
\hline Experiment & $\mathrm{O}_{1}$ & $\mathrm{X}_{\mathrm{MPBP}}$ & $\mathrm{O}_{2}$ & $\mathrm{ORE}_{1}$ & $\mathrm{ORE}_{2}$ \\
Control & $\mathrm{O}_{1}$ & $\mathrm{X}_{\mathrm{PKVL}}$ & $\mathrm{O}_{2}$ & $\mathrm{ORK}_{1}$ & $\mathrm{ORK}_{2}$ \\
\hline
\end{tabular}

This research was conducted at SMA 1 Ambon in the 2017/2018 School Year. The population in this study is all grade XI students of SMA Negeri 1 Ambon which consists of 4 classes with a total of 157 students. The samples in this study were students in grade XI IPA-1 (experiment class) and XI IPA-3 (control class), with a sample count in each class of 39 so that the total sample was 78 students. For the determination of research samples, purposive sampling techniques are used, based on the following considerations: 1) researchers hope that this study can be done effectively; 2) adjustment to learning time; 3) Researchers selected two classes as a relative research sample of their abilities not different, so it can be used precisely to know the influence of learning models on the understanding of concepts, retention and social attitudes of students.

This research was used to test and non-test instruments. Test instruments include concept comprehension tests and student retention measuring tests. The student's conceptual understanding and retention test instrument consists of multiple-choice questions. The implementation of tests to measure the understanding of student concepts is carried out at the beginning and end of the meeting. To find out the retention of students, then the implementation of the test is carried out one week after the concept comprehension test is carried out. Non-test instruments used to measure students' social attitudes, namely observation sheets with indicators including honesty, the attitude of responsibility, and attitude of teamwork. The scoring scale uses four answer options with a score of (4) always, (3) often, (2) sometimes, and (1) rarely. PjBL model is implemented with the following steps: (1) the teacher presents a problem, (2) The student identifies the problem from the teacher with the group, (3) the teacher submits the project to be done to solve the problem, (4) the teacher guides the student to create a threedimensional product about the excretion organs, (5) the student makes a threedimensional product, and (6) the student presents the results of the project to another group. Meanwhile, conventional learning is carried out according to the usual stages performed by teachers.

Data analysis uses inference statistics, namely the One Way ANOVA test to determine the influence of $\mathrm{PjBL}$ learning models and conventional learning models on the understanding of students' concepts, retention, and social attitudes, with criteria if the 
probability value or significance is $<0.05$, then it can be said that there is no influence between free variables on partially bound variables, but if the significance is $>0.05$, then it can be said that there is no significant influence between each variable free of bound variables. Before the One Way ANOVA analysis was conducted, prerequisite tests were conducted using normality and homogeneity data tests. For data analysis, use the SPSS 18.0 program.

\section{RESULTS \& DICSUSSION}

\section{Results}

Before the analysis of the hypothesis test, the data normality and homogeneity test is first conducted. Test the normality of the data using the One-Sample KolmogorovSmirnov Test, the results show that the data is distributed normally. Test homogeneity data using Leven's Test of Quality of Error Variances, the results show that the data comes from a homogeneous population.

ANOVA's One Way test results to determine the influence of PjBL models and conventional learner models on students' understanding of concepts, retention, and social attitudes. The test result of One-Way ANOVA shows that Fhit is 13,396 with a significant value of $0.000<0.05$. Based on these results, there is an influence of the learning model on understanding the concept of student excretion system material in grade XI students IPA SMA 1 Ambon. Therefore, further tests were conducted using LSD to determine the difference between each learning model and the understanding of student concepts.

The results of further LSD tests show that there is a difference in notation between PjBL learning model (notation a) and the conventional learning model (notation b) to understanding the concept of SMA Negeri 1 Ambon students. This proves that students taught using PjBL learning models have a better understanding of concepts than students taught using conventional models.

The test result of One-Way ANOVA shows that Fhit is 58,679 with a significant value of $0.000<0.05$. Based on these results, there is an influence of the learning model on the retention value of students of excretion system material in grade XI students IPA SMA 1 Ambon. Therefore, further tests were conducted using LSD to determine the difference between each learning model and student retention.

Further LSD test results show that there is a difference in notation between PjBL learning model (notation a) and the conventional learning model (notation b) against retention of SMA 1 Ambon students. This proves that students taught using the PjBL learning model have better retention scores than students taught using conventional models.

The test result of One-Way ANOVA shows that Fhit amounted to 74,993 with a significant value of $0.000<0.05$. Based on these results, there is an influence of the learning model on the social attitudes of students of grade XI IPA SMA 1 Ambon. Therefore, further tests were conducted using LSD to determine the difference between each learning model towards students' social attitudes.

The results of further LSD tests show that there is a difference in notation between PjBL (notation a) learning model and conventional learning model (notation b) towards the social attitudes of SMA 1 Ambon students. This proves that students who are taught using PjBL learning models have a better social attitude than students who are taught using conventional models. 


\section{Discussion}

\section{The Influence of Learning Models on Student Concept Understanding}

Based on the analysis of data using the ANOVA one way test (Table 3) obtained a significant value of understanding the concept of $0,000<0.05$, this means that the learning model affects understanding the concept of student excretion system material in grade XI students IPA SMA 1 Ambon. According to Kurniawan et al. (2018), the PjBL learning model is supported by constructivist learning theory, where learning emphasizes more so that students build their knowledge through their own experience. Surya et al. (2018) further argue that students are required to work autonomously to construct their studies so that each process students gain experience in-person to help students form their understanding. In addition to emphasizing the theory of constructivist learning, $\mathrm{PjBL}$ learning model also has learning stages that can direct students to empower students' understanding. Students will identify concrete problems and design project learning designs that include the manufacture of excretion organs in three-dimensional form. At the implementation stage of the project students actively perform the three-dimensional product, then actively present the structure and function of each of the excretion organs. The same is also said by Perta et al. (2017) that the learning process should be able to engage students to actively participate so that students can engage their cognitive, then can develop students' understanding of the materials they learn. Meanwhile, Rumahlatu and Sangur (2017) added that as long as students are actively carrying out project activities, students can connect the concepts that have been learned with the student's contextual experience so that an understanding of the student's concept can be formed.

In other sis, the results of further LSD (Table 4) tests show that there are significant differences (different notations) towards understanding student concepts taught using PjBL learning models and conventional learning models. PJBL's learning model is oriented towards determining problems, compiling hypotheses, conducting investigations, interpreting results, and communicating the project's work products. Through a series of project stages, the understanding of the concept of SMA 1 Ambon students experiment class can be formed. The results of this study are supported by Rumahlatu and Sangur (2019) that the application of PjBL learning model, the results show understanding of student concepts that are different from conventional learning commonly used by teachers. Learning using PjBL learning model also provides a learning experience that is different from conventional and meaningful learning for students. Rohana and Wahyudin (2016) added that meaningful learning can train students to think and increase students' interest in learning. Construction of learning with meaningful experience is a way to improve understanding of concepts better when compared to conventional learning. The same results were found by Fajrina et al. (2018) which states that students can find concepts and better adapt knowledge through given projects, this is due to the optimization of group work in project completion through various experiments.

\section{The Influence of Learning Models on Student Retention}

Based on the analysis of data using the ANOVA one way test (Table 5) obtained a significant score of $0,000<0.05$, this means that the learning model affects the retention of students of the concept of excretion system in grade XI students of IPA SMA 1 Ambon (Table 5). According to Silmiati (2017) that meaningful learning has the potential to increase student retention. The learning process using the PjBL model helps students of 
SMA Negeri 1 Ambon pack the concepts of the excretion system in their memory well. The development of a learning process oriented towards the creation of a threedimensional product on the concept of the excretion system helps students experience in real terms the concept. This makes learning more meaningful, making the concept easier for students to remember. Lubis and Manurung (2010) argue that concrete learning will be easier for students to remember than abstract learning. Retention is a term that is shown to the ability to store incoming information on a student's long-term memory. Therefore, the process of storage and recall of such information to answer the questions of the excretion system correctly relates to the theory of information processing. Budiningsih (2005) summarizes the theory of information processing as follows: information in the form of concepts accepted by the student's senses, then stored in the short-term memory of the student; information in a student's short-term memory is stored in coding i.e. the process of transforming new information integrated with old information is then stored in the student's long-term memory. Students who have strong retention, mean students can store and recall concepts that are coming from a student's long-term memory. Project-based learning stages focus on students' cognitive constructivist, so that information processing can be stored in students' long-term memory.

On the other hand, the results of the LSD advanced test (Table 6) show that the retention of students taught using PjBL learning models and conventional learning models differs significantly. Through PjBL learning model students can develop their retention so that it is different from students taught using conventional learning models. These differences are based on the characteristics of the learning model used by teachers, the characteristics and abilities of students that cannot be controlled by the teacher. It is explained by Nusantari (2018) that factors that affect retention, namely the selection of learning strategies/ learning models, material characteristics, the academic ability of students, the timing of implementation of retention tests, and internal factors. Lubis and Simatupang (2014) added that the factor that contributes to retention is the activeness of students during the learning process. PjBL learning models have more dominant learning stages to train students' activeness to affect student retention. These stages include identifying problems, designing project designs, being active in product manufacturing, and being active in product contraction. Sukmawati et al. (2015) said that the implementation of discussions and interactions between students also empowers student retention. During PjBL's learning, students work with their groups and discuss each other to help students build and strengthen student retention.

\section{The Influence of Learning Models on Students' Social Attitudes}

Based on the analysis of data using the ANOVA one way test (Table 7) obtained a significant score of $0,000<0.05$, this means that the learning model affects the social attitudes of students of grade XI IPA SMA 1 Ambon. According to Gusviani (2016), those social attitudes are the domain of the affective realm that plays a very important role in giving birth to a young generation of noble people. Social attitudes are one of the crucial attitudes to grow in biology learning so that biology learning is not only an understanding of the concept of biology but also the development of social attitudes. This is useful in educating students to interact with peers, teachers, and the community in their environment. It was affirmed by Kusrahmadi (2007) that education not only transfers science to students but also transfers moral values and universal humanitarian values.

On the other hand, the results of the LSD advanced test (Table 8) show that students' social attitudes taught using PjBL learning models and conventional learning models differ significantly (Table 8). The average social attitude of students taught using 
the project learning model is higher than the learning model commonly used by teachers (convention learning). This shows that through $\mathrm{PjBL}$ learning model, students can develop their social attitudes so that it is different from students taught using conventional learning models. Project-based learning is learning that prioritizes the activeness of students in learning (Aryani et al., 2017). During learning using project-based learning models, students can actively develop students' social attitudes. Project-based learning syntax/stages can empower students to interact and collaborate to formulate problems, create products, get to the presentation stage. The interactions that occur within this group involve students to develop an honest, honest, and responsible attitude. It was reported by Wulandari et al. (2016) that the aspects of social attitudes that develop during the investigation process are honest, responsible, polite, and caring. Also, students' social attitudes are heavily influenced by their social environment. The neighborhood is a family, school, and community environment. The intended category of the school environment is the environment or condition during the learning process. If students are surrounded by a positive learning environment, it can help students to empower positive attitudes, otherwise, if the student's learning environment is negative it will affect the student's attitude to be negative (Danim, 2011). This research shows that the learning environment using the PjBL learning model can empower students' social attitudes better when compared to students' social attitudes during learning using the learning model commonly used by teachers.

\section{CONCLUSION}

Based on the research that has been done, the conclusion of this study, as follows: (1) Model project-based learning (PjBL) affects the increasing understanding of the concept of excretion system of students grade XI IPA 1 Ambon. (2) The project-based learning $(\mathrm{PjBL})$ model affects student retention in understanding the concept of the excretion system. (3) The project-based learning (PjBL) model affects students' social attitudes in understanding the concept of the Excretion system.

\section{ACKNOWLEDGEMENT}

Thank you to the Governor of Maluku who has provided scholarships for teachers to continue their studies in biology, postgraduate education study program, Pattimura University. Thank you also to the reviewers who have corrected this article.

\section{REFERENCES}

Aryani, A. K., Suwono, H., \& Parno. (2017). Peningkatan hasil belajar peserta didik melalui pembelajaran berbasis proyek dengan peer assessment pada konsep klasifikasi makhluk hidup. Jurnal Pendidikan: Teori, Penelitian, dan Pengembangan, 2(8), 1141-1148. http://dx.doi.org/10.17977/jptpp.v2i8.9908

Bhinnety, M. (2008). Struktur dan proses memori. Buletin Psikologi, 16(2), 74-88. https://doi.org/10.22146/bpsi.7375

Budiningsih. (2005). Belajar dan pembelajaran. Jakarta: Rineka Cipta.

Fajrina, R. N. A. A., Handayanto, S. K., \& Hidayat, A. (2018). Peran model project based learning dalam kemampuan berpikir kreatif kelas XI IPA melalui materi fluida 
statis. Jurnal Pendidikan: Teori, Penelitian, dan Pengembangan, 3(3), 291-295. http://dx.doi.org/10.17977/jptpp.v3i3.10625

Gusti, S. W. (2017). Analisis hasil implementasi Kurikulum 2013 dalam aspek sikap, pengetahuan,dan keterampilan pada mata pelajaran biologi SMA di Kabupaten Sleman Yogyakarta. Jurnal Prodi Pendidikan Biologi, 6(5), 312-322. Retrieved from http://journal.student.uny.ac.id/ojs/index.php/pbio/article/viewFile/8127/773 3

Gusviani, E. (2016). Analisis kemunculan sikap spiritual dan sikap sosial dalam kegiatan pembelajaran IPA Kelas IV SD yang menggunakan KTSP dan Kurikulum 2013. Edu Humaniora: Jurnal Pendidikan Dasar, 8(1), 96-100. https://doi.org/10.17509/eh.v7i2.2706

Jagantara, I. M. W., Adnyana, P. B., \& Widiyanti, N. L. (2014). Pengaruh model pembelajaran berbasis proyek (project based learning) terhadap hasil belajar biologi ditinjau dari gaya belajar siswa SMA. e-Journal Program Pascasarjana Universitas Pendidikan Ganesha Program Studi IPA, 4(1), 1-12.

Kusrahmadi, S, D. (2007). Pentingnya pendidikan moral bagi anak Sekolah Dasar. Dinamika Pendidikan, 1(14), 118-130.

Kurniawan, H. R., Elmunysah, H., \& Muladi. (2018). Perbandingan penerapan model pembelajaran project based learning dan think pair share berbantuan modul ajar terhadap kemandirian dan hasil belajar siswa kelas XI di SMKN 3 Malang. Jurnal Pendidikan, 3(2), 80-85. http://dx.doi.org/10.26740/jp.v3n2.p80-85

Latief, H., Rohmat, D., \& Ningrum, E. (2014). Pengaruh pembelajaran kontekstual terhadap hasil belajar (studi eksperimen pada mata pelajaran geografi kelas VII di SMPN 4 Padalarang). Jurnal Pendidikan Geografi, 14(2), 14-28. https://doi.org/10.17509/gea.v14i2.3395

Lestari, P. \& Sukanti. (2016). Membangun karakter siswa melalui kegiatan intrakurikuler ekstrakurikuler, dan hidden curriculum (di SD Budi Mulia Dua Pandeansari $\begin{array}{llll}\text { Yogyakarta). Jurnal } & \text { Penelitian, }\end{array}$ http://dx.doi.org/10.21043/jupe.v10i1.1367

Lubis, N. F., \& Simatupang, Z. (2014). Peningkatan daya retensi siswa terhadap konsepkonsep biologi melalui pemanfaatan media adobe flash pada model pembelajaran langsung. Prosiding Seminar Nasional Biologi dan Pembelajarannya, 654-664.

Lubis, A. R., \& Manurung, B. (2010). Pengaruh Model dan Media Pembelajaran Terhadap Hasil Belajar dan Retensi Siswa Pada Pelajaran Biologi Di SMP Swasta Muhamadiah Serbelawan. Jurnal Pendidikan Biologi, 1(3): 186-206

Meyer, J. H. F., \&. Land, R., (2005). Threshold concepts and troublesome knowledge (2): Epistemological considerations and a conceptual framework for teaching and learning. Higher Education, 49, 373-388. https://doi.org/10.1007/s10734-0046779-5

Nusantari, E. (2018). Kajian faktor yang mempengaruhi retensi siswa SMA (Analisis hasil penelitian eksperimen dan PTK). Prosiding Seminar Nasional Universitas Gorontalo, $1-17$. Retrieved from http://repository.ung.ac.id/karyailmiah/show/1521/kajian-faktor-yangmempengaruhi-retensi-siswa-SMA-analisis-hasil-penelitian-eksperimen-danptk.html

Perta, P. A., Ansori, I., \& Karyadi, B. (2017). Peningkatan aktivitas dan kemampuan menalar siswa melalui model pembelajaran siklus belajar 5E. Diklabio: Jurnal Pendidikan dan Pembelajaran Biologi, 1(1), 72-82. https://doi.org/10.33369/diklabio.1.1.72-81

Patton, A. (2012). Work that matters the teacher's guide to project-based learning. Published by the Paul Hamlyn Foundation. Retrieved from 
https://www.innovationunit.org/wp-content/uploads/2017/04/Work-That-MattersTeachers-Guide-to-Project-based-Learning.pdf

Pardo, L. S. (2004). What every teacher needs to know about comprehension. The Reading Teacher, 58(3), 272-280. https://doi.org/10.1598/RT.58.3.5

Rumahlatu, D., \& Sangur, K. 2019. The influence of project-based learning strategies on the metacognitive skills, concept understanding, and retention of senior high school students. Journal of Education and Learning, 13(1), 104-110. https://doi.org/10.11591/edulearn.v13i1.11189

Rumahlatu, D. \& Sangur, K. (2017). Implementation of project-based learning strategies to improve metacognitive skills and understanding of biodiversity concepts in state high school 2 Kairatu, West District of Seram. The $2^{\text {nd }}$ International Seminar on Education. 1, 43-48. Retrieved from https://ojs.unpatti.ac.id/index.php/ises/article/view/127/79

Rohana, R. S., \& Wahyudin, D. (2016). Project based learning untuk meningkatkan berpikir kreatif siswa SD pada materi makanan dan kesehatan. Jurnal Penelitian Pendidikan, 16(3), 235-243. Retrieved from https://ejournal.upi.edu/index.php/JER/article/view/4817/3373

Sastrika, I. A. K., Sadia, I. W., \& Muderawan, I. W. (2013). Pengaruh model pembelajaran berbasis proyek terhadap pemahaman konsep kimia dan keterampilan berpikir kritis. Jurnal Pendidikan dan Pembelajaran IPA Indonesia, 3(2), 1-10. Retrieved from http://ejournalpasca.undiksha.ac.id/index.php/jurnal_ipa/article/view/799

Silmiati, N. Y. (2017). Perbandingan retensi siswa SMP pada pembelajaran IPA terpadu konsep cahaya antara model pembelajaran berbasis masalah dan metode pembelajaran inkuiri. Jurnal Penelitian Pendidikan, 17(1), 60-68. Retrieved from https://ejournal.upi.edu/index.php/JER/article/view/6637/4511

Sufahmi, A., \& Safitri, R. (2017). Peningkatan Ketuntasan Belajar Dan Sikap Sosial Peserta Didik Melalui Pemberian Reward Untuk Tutor Sebayapada Konsep Gerak Harmonik Sederhana. Jurnal Pendidikan Sains Indonesia, 5(2), 10-18. https://doi.org/10.24815/jpsi.v5i2.9808

Sukmawati, I., Ramadani, S. D., Fauzi, A., \& Corebima, A. D. (2015). Perbedaan pemberdayaan retensi antara siswa SMA akademik rendah dan tinggi melalui pembelajaran cooperative script dalam pembelajaran biologi. Prosiding Seminar Nasional Biologi/IPA dan Pembelajarannya, 662-667.

Surya, A. P., Relmasira, S. C., \& Hardini, A. T. A. (2018). Penerapan model pembelajaran project based learning $(\mathrm{PjBL})$ untuk meningkatkan hasil belajar dan kreatifitas siswa kelas III SD Negeri Sidorejo Lor 01 Salatiga. Jurnal Pesona Dasar, 6(1), 41-54. https://doi.org/10.24815/pear.v6i1.10703

Susilo, M. J. (2016). Pembelajaran IPA biologi berbasis scientific approach di SMP Muhammadiyah 2 Depok Sleman. Proceeding Biology Education Conference, 13(1), 97-101. Retrieved from https://jurnal.uns.ac.id/prosbi/article/view/5666

Trianto. (2014). Model pembelajaran terpadu: Konsep, strategi, dan implementasinya dalam kurikulum tingkat satuan pendidikan (KTSP). Jakarta: Bumi Aksara.

Winarti, T. \& Nurhayati, S. (2014). Pembelajaran praktikum berorientasi proyek untuk meningkatkan keterampilan proses sains dan pemahaman konsep. Jurnal Inovasi Pendidikan Kimia, 8(2), 1409-1420.

Wulandari, V. C. P., Al-Muhdhar, M. H. I., \& Suhadi. (2016). Pembelajaran role playing dipadu group investigation berbantuan komik program KRPL sebagai upaya untuk mengembangkan kemampuan kognitif dan sikap sosial. Jurnal Pendidikan: Teori, Penelitian, dan Pengembangan, 1(6), 1191-1195. http://dx.doi.org/10.17977/jp.v1i6.6473 
Yance, R. D., Ramli, E., \& Mufit, F. (2013). Pengaruh penerapan model project based learning terhadap hasil belajar fisika siswa kelas XI IPA SMA Negeri 1 Batipuh Kabupaten Tanah Datar. Pillar of Physics Education, 1(1), 1-11. http://dx.doi.org/10.24036/490171074

Yustyan, S., Widodo, N., \& Pantiwati, Y. (2015). Peningkatan kemampuan berpikir kritis dengan pembelajaran berbasis scientific approach siswa kelas X SMA Panjura Malang. Jurnal Pendidikan Biologi Indonesia, 1(2), 240-254. https://doi.org/10.22219/jpbi.v1i2.3335 